\title{
COFFEE RESIDUES AS SUBSTRATES FOR AROMA PRODUCTION BY CERATOCYSTIS FIMBRIATA IN SOLID STATE FERMENTATION
}

\author{
Adriane Bianchi Pedroni Medeiros ${ }^{1}$; Pierre Christen²; Sevastianos Roussos²; Juliana Carine Gern; \\ Carlos Ricardo Soccol ${ }^{1 *}$
}

${ }^{1}$ Laboratório de Processos Biotecnológicos, Departamento de Engenharia Química, Universidade Federal do Paraná, Curitiba, PR, Brasil. ${ }^{2}$ Laboratoire de Microbiologie, IRD, Université de Provence, Marseille, France.

Submitted: November 01, 2001; Approved: June 26, 2003

\begin{abstract}
The ability of two different strains of Ceratocystis fimbriata for fruity aroma production by solid state fermentation (SSF) was tested on coffee pulp and coffee husk complemented with glucose as substrates. Experiments were carried out in $250 \mathrm{~mL}$ Erlenmeyer flasks and the experimental conditions were: $70 \%$ of initial moisture, $20 \%$ of glucose addition and $\mathrm{pH}$ 6.0. Aeration was made by passive diffusion through the gauze covering the flasks. Headspace analysis of the culture by gas chromatography (GC) showed that 12 compounds were produced with coffee husk. Maximum total volatiles (TV) concentration was reached after $72 \mathrm{~h}$ of culture with coffee husk as substrate $\left(28 \mu \mathrm{mol} \cdot \mathrm{L}^{-1} \cdot \mathrm{g}^{-1}\right)$. Ethyl acetate, ethanol and acetaldehyde were the major compounds produced, representing $84.7 \%, 7.6 \%$ and $2.0 \%$ of TV, respectively. A pre-treatment with heat $\left(100^{\circ} \mathrm{C} / 40 \mathrm{~min}\right)$ of substrates did not improve $\mathrm{TV}$ production. Respirometry analysis was used to determine the growth of the culture by measuring carbon dioxide produced. Results showed that the $\mathrm{CO}_{2}$ production follows the aroma production. This result shows the great potential for the use coffee pulp and coffee husk as substrates to microbial aroma production by solid state fermentation.
\end{abstract}

Key words: Ceratocystis fimbriata, coffee residues, solid state fermentation, aroma.

\section{INTRODUCTION}

The tropical agro-industrial residues such as coffee pulp and coffee husk, cassava bagasse, sugar cane bagasse are generated in large amounts during the processing and their disposal rather causes serious environmental problems. In recent years, there has been constant increase in the efforts to utilize these residues as substrate (carbon source) in bioprocesses (8). Microorganisms play an important role in the generation of natural compounds, particularly in the field of food aromas $(1,5,6)$. Solid state fermentation (SSF) has been used for the production of aroma compounds by cultivating yeasts and fungi such as Neurospora sp. (10), Kluyveromyces marxianus (7), Trichoderma viride (4), using pre-gelatinized rice, cassava bagasse and agar, respectively. Christen et al. (3) explored the production of intense fruity aroma by Ceratocystis fimbriata in
SSF using wheat bran, cassava bagasse and sugar cane bagasse as substrates. Bramorski et al. (2) reported the production of volatile compounds by growing Ceratocystis fimbriata on tropical agro-industrial residues.

The aim of present work was to evaluate the production of aroma compounds in SSF by Ceratocystis fimbriata using coffee husk and coffee pulp as substrates.

\section{MATERIALS AND METHODS}

\section{Microorganism and inoculum}

Two strains of Ceratocystis fimbriata (CBS 374.83; CBS 146.53) were used in this study. They were maintained on potato dextrose agar (PDA) and stored at $4^{\circ} \mathrm{C}$. Spores suspensions were prepared after 5 days of culture at $30^{\circ} \mathrm{C}$ in $250 \mathrm{~mL}$ Erlenmeyer flasks. Spores were collected with sterile distilled

*Corresponding author. Mailing address: Laboratório de Processos Biotecnológicos, Departamento de Engenharia Química, Universidade Federal do Paraná.81531-970, Curitiba, PR, Brasil. Telephone: (+5541) 266-0222. E-mail: soccol@ufpr.br 
water containing a few drops of Tween 80 and small glass beads. The spores suspensions contained $10^{8}$ spores $/ \mathrm{mL}$ counted using the Neubauer's chamber.

\section{Preparation of substrates}

Coffee pulp and coffee husk were dried at $60^{\circ} \mathrm{C}$ in an air oven for $24 \mathrm{~h}$. The dried substrates was milled and sieved to obtain particles of $0.8-2.0 \mathrm{~mm}$ size. In order to investigate the most appropriate substrate for aroma production, a thermal treatment at $100^{\circ} \mathrm{C}$ during $40 \mathrm{~min}$ were applied to substrates according to Soares et al. (12).

\section{Fermentation procedure}

SSF was carried out in $250 \mathrm{~mL}$ Erlenmeyer flasks containing $15 \mathrm{~g}$ of substrate (dry weight basis). This was enriched with glucose $(20 \%)$. After setting the initial $\mathrm{pH}$ at 6.0 and moisture at $70 \%$, the substrates were autoclaved at $121^{\circ} \mathrm{C}$ for $15 \mathrm{~min}$ and inoculated using $1 \times 10^{7}$ spores/g initial dry matter (IDM). The flasks were incubated at $30^{\circ} \mathrm{C}$. All experiments were done in triplicates.

\section{Analytical procedures}

Aroma compounds produced were measured in the headspace of the culture with a HP $6890 \mathrm{GC}$, equipped with a flame ionization detector at $230^{\circ} \mathrm{C}$. The operating conditions were: a $30 \mathrm{~m}$ x $0.32 \mathrm{~mm} \mathrm{HP}-5$ capillary column, column temperature from $40^{\circ} \mathrm{C}$ to $150^{\circ} \mathrm{C}$ at a rate of $20^{\circ} \mathrm{C} / \mathrm{min}$, injector temperature $230^{\circ} \mathrm{C}$. Total and individual volatile were expressed as $\mu$ mol per liter of headspace, as ethanol equivalent. The standards compounds were used to identify microbial aroma produced. The respirometric analysis of culture was realized with a gas chromatography to quantify the oxygen uptake rate and carbon dioxide produced. These measures are often used for an indirect evaluation of biomass and are important to scale up SSF process $(9,11)$.

\section{RESULTS AND DISCUSSION}

Initial studies were carried out in $250 \mathrm{ml}$ Erlenmeyer flasks using coffee pulp and coffee husk as substrates. According to the results obtained by Soares et al. (10), the best conditions to maximize volatile compounds produced by $C$. fimbriata on coffee husk were: $\mathrm{pH} 6.0,70 \%$ of initial water content, $30^{\circ} \mathrm{C}$, inoculum rate $1 \times 10^{7}$ cells/g IDM and $20 \%$ of glucose addition. The same conditions were applied to the experiments with coffee pulp.

\section{Total volatile compounds production}

As is shown in Fig. 1, maximum total volatile (TV) concentration was obtained after $48 \mathrm{~h}$, with $C$. fimbriata CBS 374.83 cultivated on coffee husk without treatment. A pretreatment with heat $\left(100^{\circ} \mathrm{C} / 40 \mathrm{~min}\right)$ of substrates did not improve
TV production. A total of thirteen compounds were produced from both coffee substrates. Out of which ethyl acetate, ethanol and acetaldehyde were the major compounds. Other eight compounds included ethyl propionate, propyl acetate, ethyl isobutyrate, butyl acetate. Four compounds remained unidentified. Table 1 shows the percentage of each individual compound produced by $C$. fimbriata CBS 374.83 at different substrates, as accumulated in the headspace at their maximum concentration. Experiments with C. fimbriata CBS 146.53 (Fig. 2) resulted decreased production of total volatile compounds, when compared with $C$. fimbriata $\mathrm{CBS} 374.83$. We can observe different comportment of the synthesis of volatiles by this two strain. The culture of $C$. fimbriata CBS 146.53 on coffee husk

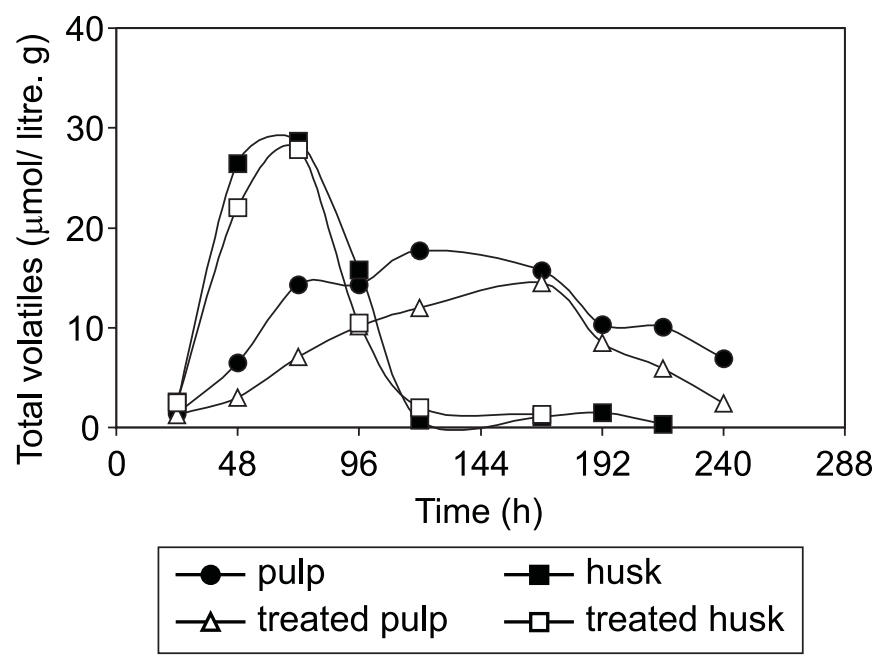

Figure 1. Total volatile compounds evolution for experiments with Ceratocystis fimbriata CBS 374.83 on different substrates.

Table 1. Production of volatiles compounds by Ceratocystis fimbriata CBS 374.83 on different substrates. Values represented in percentage of total volatiles.

\begin{tabular}{lccrc}
\hline $\begin{array}{c}\text { Substrate } \\
\text { Compound }\end{array}$ & $\begin{array}{c}\text { Coffee } \\
\text { husk }\end{array}$ & $\begin{array}{c}\text { Treated } \\
\text { coffee husk }\end{array}$ & $\begin{array}{c}\text { Coffee } \\
\text { pulp }\end{array}$ & $\begin{array}{c}\text { Treated } \\
\text { coffee pulp }\end{array}$ \\
\hline Acetaldehyde & 2.0 & 0.6 & 2.1 & 0.6 \\
Ethanol & 7.6 & 1.9 & 20.0 & 2.0 \\
A & 0.3 & 0.6 & 1.4 & 1.8 \\
B & 0.3 & 0.5 & 0.2 & 2.0 \\
Ethyl Acetate & 84.7 & 92.9 & 69.6 & 75.8 \\
Ethyl Propionate & 1.6 & 1.1 & 0.8 & 1.0 \\
Propyl Aceta & 0.4 & 0.2 & 0.6 & 0.2 \\
Isobutyl acetate & 0.8 & 0.9 & 0.5 & 0.8 \\
Ethyl isobutyrate & 0.8 & 0.8 & 0.6 & 0.7 \\
Ethyl butyrate & 0.4 & 0.5 & 0.3 & 0.4 \\
C & 0.3 & 0 & 0 & 0 \\
D & 0.8 & 0 & 3.9 & 14.7 \\
\hline
\end{tabular}



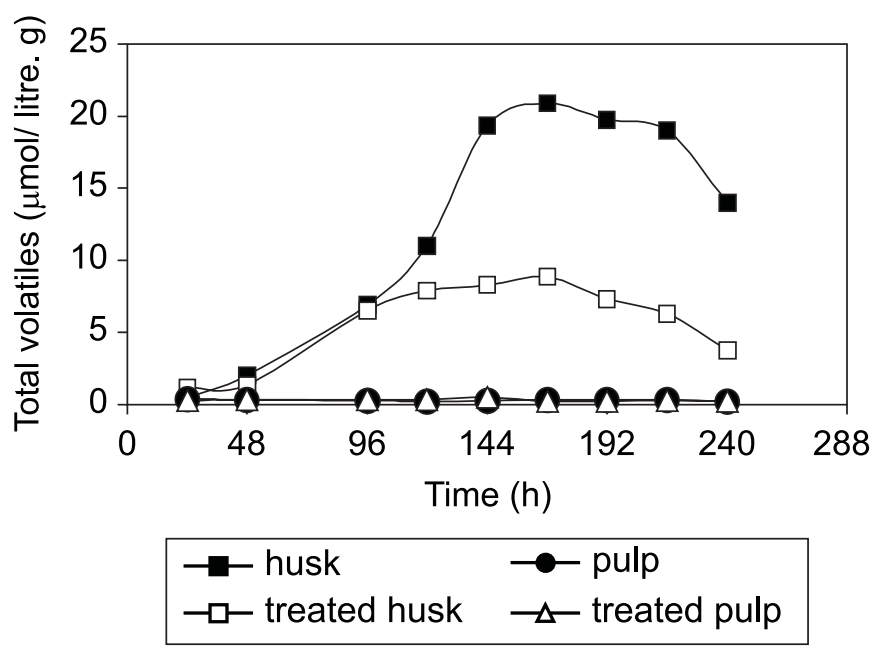

Figure 2. Total volatile compounds evolution for experiments with Ceratocystis fimbriata CBS 146.53 on different coffee residue as substrates.

shows a longer "lag phase" than that observed for the other strain. Coffee pulp untreated or treated were not good substrates for volatiles compounds production.

The presence of fruity aroma produced by the culture was attributed to the esters production, as it is known that alcohols do not contribute any flavour, although together with other compounds affect the overall flavour quality. We believed that the concentration of volatile compounds in the headspace of the culture is generally affected by several factors, chiefly with the nature and concentration of the fermentation medium and its vapor pressure. There could be the possibility that the compounds, which are less volatile in nature, might not be accurately measured.

\section{Respirometric analysis}

The maximum respirometric activity, represented by carbon dioxide produced and oxygen consumed (Fig 3), was observed at $48 \mathrm{~h}$ of fermentation. Maximum total volatile concentration was as well detected at $48 \mathrm{~h}$. These results showed that volatile compounds production dependent of the fungus growth. The microbial culture used the carbon source and oxygen for growth and maximum production of TV was just before or after the maximal biomass growth. The oxygen and substrate were used by the fungus not only for biomass and $\mathrm{CO}_{2}$ production, but for metabolites production (volatile compounds). After $48 \mathrm{~h}$ of fermentation, $\mathrm{CO}_{2}$ production was decreased. Bramorski et al. (2), using $\mathrm{CO}_{2}$ production as a growth indicator, also found correlation between the growth of $C$. fimbriata on different medium and production of the volatile compounds, showing that the maximum volatile production always occurred a few hours before or after the maximum respirometric activity.

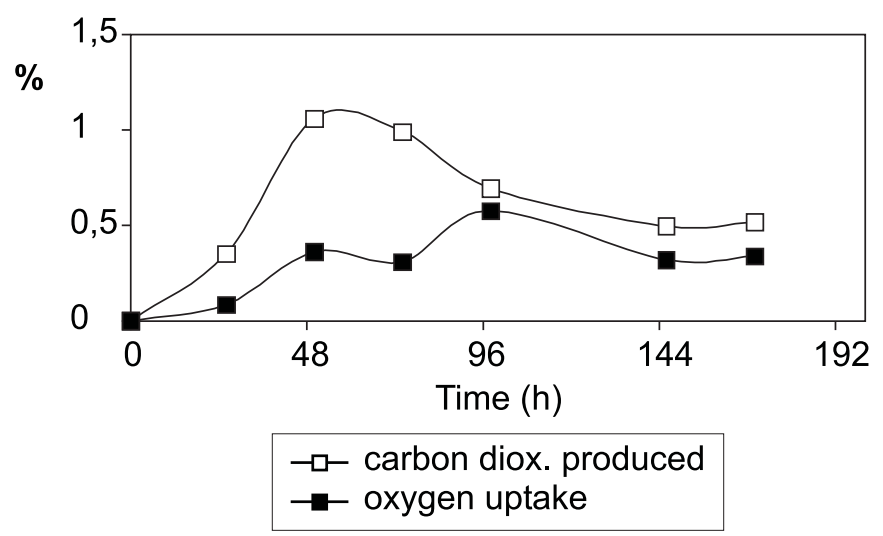

Figure 3. Carbon dioxide produced (\%) and oxygen uptake (\%) by Ceratocystis fimbriata CBS 374.83 cultivated on coffee husk.

Coffee husk was found an adequate substrate for aroma production by $C$. fimbriata. Twelve compounds were separated by GC headspace analysis of the culture. The predominant compounds were ethyl acetate, ethanol and acetaldehyde. The influence of the thermal treatment on volatile production was not demonstrated. A correlation was observed between growth and volatile compound production.

\section{ACKNOWLEDGMENTS}

Financial assistance from the European Union and CAPES for a scolarship. CRS thanks CNPq for a scholarship under Scientific Productivity Scheme.

\section{RESUMO}

\section{Produção de aromas por Ceratocystis fimbriata em fermentação no estado sólido utilizando resíduos da agroindústria do café como substratos}

Neste trabalho duas diferentes cepas de Ceratocystis fimbriata foram testadas para a produção de aromas frutais em fermentação no estado sólido (FES) utilizando como substratos casca e polpa de café, suplementados com glicose. Os experimentos foram realizados em frascos Erlenmeyer de $250 \mathrm{~mL}$. As condições experimentais foram: umidade inicial de $70 \%$, adição de $20 \%$ de glicose e $\mathrm{pH}$ 6,0. Os frascos foram cobertos com gaze e a aeração ocorreu por difusão passiva. A análise do "headspace" da cultura foi feita por cromatografia gasosa e 12 compostos foram detectados utilizando a casca de café. A análise respirométrica foi realizada para o acompanhamento do crescimento do microrganismo pela determinação do dióxido de carbono produzido. A produção de ésteres caracterizou o aroma frutal da cultura. A concentração máxima de voláteis totais foi alcançada após 
$72 \mathrm{~h}$ de cultivo em casca de café $\left(28 \mu \mathrm{mol} \cdot \mathrm{L}^{-1} \cdot \mathrm{g}^{-1}\right)$. Os principais compostos produzidos foram acetato de etila, etanol e acetaldeído, representando $84,7 \%, 7,6 \%$ and $2,0 \%$ dos voláteis totais, respectivamente.

Palavras-chave: Ceratocystis fimbriata, café, resíduos, fermentação no estado sólido

\section{REFERENCES}

1. Berger, R.G. Aroma Biotechnology, Springer-Verlag, Berlin, 1995.

2. Bramorski, A.; Soccol, C.R.; Christen, P.; Revah, S. Fruity aroma production by Ceratocystis fimbriata in solid cultures from agroindustrial wastes. Rev. Microbiol., 28:208-212, 1998b.

3. Christen, P.; Meza, J.C.; Revah, S. Fruity aroma production in solid state fermentation by Ceratocystis fimbriata: influence of the substrate type and the presence of precursors. Mycol. Res., 101:911-919, 1997.

4. Gervais, P.; Sarrette, M. Influence of age of mycelia and water activity on aroma production by Trichoderma viride. J. Ferment. Bioeng., 69:46-50, 1990.

5. Janssens, L.; de Pooter, H.L.; Schamp, N.M.; Vandamme, E.J. Production of flavours by micro-organisms. Process Biochem., 27:195-215, 1992.
6. Jiang, J. Changes in volatile composition of Kluyveromyces lactis broth during fermentation. In: Charalambous, G. (ed.). Food Flavours, Analysis and Process Influence. Elsevier Science B.V., 1073-1086, 1995.

7. Medeiros, A.B.P.; Pandey, A.; Freitas, R.J.S.; Christen, P.; Soccol, C.R. Optimization of the production of aroma compounds by Kluyveromyces marxianus in solid state fermentation using factorial design and response surface methodology. Biochem. Eng. J., 6:3339, 2000.

8. Pandey, A.; Soccol, C.R. Bioconversion of biomass: a case study of lignocellulosic bioconversions in solid state fermentation. Braz. Arch. Biol. Technol., 41:379-390, 1998.

9. Pandey, A.; Soccol, C.R.; Rodrigues-Leon, Nigam, P. Solid-State Fermentation in Biotechnology: Fundamentals and Aplications. Asiatech Publishers Inc, 2001, 221p.

10. Pastore, G.M.; Park, Y.K.; Min, D.B. Production of a fruity aroma by Neurospora from beiju. Mycol. Res., 98:25-35, 1994.

11. Saucedo-Castañeda, G.; Trejo-Hernández, M.R.; Lonsane, B.K.; Navarro, J.M.; Roussos, S.; Dufour, D.; Raimbault, M. On-line automated monitoring and control systems for $\mathrm{CO}_{2}$ and $\mathrm{O}_{2}$ aerobic and anaerobic solid state fermentations. Process Biochm., 29:1324, 1994.

12. Soares, M.; Christen, P.; Pandey, A.; Soccol, C.R. Fruity flavour production by Ceratocystis fimbriata grown on coffee husk in solidstate fermentation. Process Biochemistry, 35:857-861, 2000. 